\title{
Modern városok programja: új fejezet a magyar várospolitikában
}

\section{Modern Cities Program: new chapter in the Hungarian urban policy}

GAJZÁGÓ GERGŐ

\begin{abstract}
GAJZÁGó Gergő: tudományos segédmunkatárs, MTA Közgazdaság- és Regionális Tudományi Kutatóközpont, Regionális Kutatások Intézete; 7601 Pécs, Pf. 199.; gajzago.gergo@sze.hu; https://orcid.org/0000-0001-5061-8691
\end{abstract}

KULCSSZAVAK: várospolitika; Modern városok program; városfejlesztés; városhálózat

ABSZTRAKT: Jelen tanulmány a Modern városok programját (MVP) elemzi. A program a megyei jogú városokat célozza, amelyek a vidéki városhálózat meghatározó központjai, így az MVP az egész magyar városhálózatra hatással lesz, amennyiben projektjei megvalósulnak. A program - írásban nem olvasható - céljai szakmailag támogathatók, a kétszázötvennyolc azonosított projekt közel fele megjelenik korábbi fejlesztési stratégiákban is. A kormányzat által ígért 3400-3500 milliárd Ft költségvetésből a kutatás során 2683,2 milliárd Ft-ot tudtunk azonosítani, ami így is nagyon jelentős összegnek tekinthető. A tanulmány ágazati és területi megoszlás alapján is vizsgálja a költségvetést és a projekteket, végül pedig figyelmet szentel a program menedzsmentjének és kommunikációjának központi és helyi szinten egyaránt. Véleményünk szerint érdemes a területi politika ezen új elemét részletesebb vizsgálat alá vonni, azt elemezni, hogy az új program hogyan illeszkedik a korábbi várospolitikai eszközök sorába, mennyire van összhangban a helyi fejlesztési elképzelésekkel, és milyen hatásokat várhatunk a megvalósulásától. Az elemzés röviden kitér arra is, hogy az MVP miként segíti az érintett városok fejlődését, azok kapcsolódását az Enyedi György által azonosított sikertényezőkhöz. A tanulmány javaslatokat fogalmaz meg arra vonatkozóan, hogy hogyan lehetne az MVP sikerességét erősíteni, jelenleg ugyanis bizonytalan, hogy a program keretében hány projektet valósítanak meg.

Gergö GAJZÁGÓ: junior research fellow, Institute for Regional Studies, Centre for Economic and Regional Studies, Hungarian Academy of Sciences; Pf. 199., H-7601 Pécs, Hungary; gajzago.gergo@sze.hu; https://orcid.org/0000-0001-5061-8691

KEYWORDS: urban policy; Modern Cities Program; city development; city network

ABSTRACT: This paper analyses the Modern Cities Program (MCP) with the key question of whether the MCP is a new chapter in Hungarian urban policy and whether it contributes to the successful development of cities. From a historical point of view, the programme follows earlier trends, as Hungary has not yet had an explicit urban policy. The MCP has not changed that.

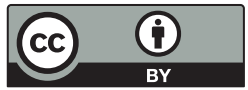


The programme was launched in March 2015 and focused on the county-level cities, which are the defining elements of the Hungarian urban network. Thus, if its projects are implemented, the MCP will have an impact on the entire Hungarian urban network. The programme has a strongly political character: the Prime Minister has personally launched the programme in each city by agreeing on a local project list. The MCP has no official documentation in the form of a preliminary impact assessment, concept or implementation provisions. However, the objectives of the programme are known and considered to be appropriate.

Almost half of the 258 identified projects feature in previous development strategies, but the extent varies from city to city (0-82\%). The government estimates the expenditure at about 10.5-10.8 billion euros, but only 8.3 billion euros could be identified in our research, a considerable amount after all. The budget was analysed according to sectors and spatial distribution. It shows that the allocation of funds for transport projects is dominant (73.5\%). The reason for this is that the expansion of motorways and railways is included in the programme. But even without these large extra-urban infrastructure measures, most of the resources are earmarked for transport projects.

Typical projects are an intermodal transport centre, the creation of new industrial areas, the renovation of theatres, the construction of sports centres and hotels and the renovation and extension of secondary schools. An analysis of spatiality shows that without the major infrastructure projects (30), all of which inevitably have a regional impact, the following breakdown can be seen: $5 \%$ have a regional impact, $27 \%$ are regional in function and $68 \%$ have urban reach.

Finally, management and communication of the program were studied at central and local levels. The first two years produced few results, after which a minister with no portfolio was entrusted with the MCP. But after the national elections of 2018, this office was not filled again. Only one city has its own organisational unit for coordinating the MCP projects, and only two cities have detailed information about the projects on their web portal.

The author considers the analysis of this new mechanism of regional policy to be useful because it shows how the MCP fits into the history of previous urban policy, how it harmonises with local development concepts and what effects can be expected. Finally, the paper discusses the connection between MCP and Enyedi's catalogue for a successful city and outlines some policy proposals.

\section{Bevezetés}

A 2010 utáni területi kormányzásban megjelenő új típusú centralizáció eszközei a nagy nemzeti kezdeményezések, amelyek segítségével a központi kormányzat irányítani, koordinálni kívánja a helyi fejlesztéseket és maga osztja el a fejlesztésekre elkülönített források jelentős részét. Többek közt a forrásait tekintve a legnagyobb ilyen kezdeményezés a Modern városok programja, amelynek legfőbb jellemzői:

- helyi fejlesztésekre irányul;

- a területi politika fontos alakítója;

- a végső döntéseket központilag hozzák meg;

- a helyi döntéshozók bevonása bizonyos mértékben megvalósul;

- ugyanakkor a helyi társadalom bevonása nem jellemző;

- fontos részét képezte a kormányzati kommunikációnak (a választások előtt);

- nincs egységes dokumentációja, előzetes vizsgálata, leírt koncepciója; 
- a program eredményességét, hatását nem vizsgálják;

- a megvalósítás nem átlátható;

- a program pontos lehatárolása, számszerűsítése hiányos, illetve az elérhető dokumentációk hiánya miatt nehézkes.

Jelen tanulmányban a Modern városok programjáról (továbbiakban MVP) folytatott kutatás eredményeit mutatom be. Az MVP a kormányzat által kommunikált 3 400-3 500 milliárd forintnyi fejlesztési összegével várhatóan nagy hatással lesz a megyei jogú városok - és így közvetve a magyar városhálózat - fejlődésére, amennyiben megvalósul. Ezért is érdemes a területi politika ezen új elemét részletesebb vizsgálat alá vonni, elemezni, hogy az új program hogyan illeszkedik a korábbi várospolitikai eszközök sorába, mennyire áll összhangban a helyi fejlesztési elképzelésekkel, milyen hatásokat várhatunk a megvalósulásától, és milyen tudományos megalapozottsággal rendelkezik mint fejlesztéspolitikai eszköz. Az elemzés egyik kutatási kérdése, hogy az MVP hogyan segíti az érintett városok fejlődését. Ahogy Fekete (2017b, 99.) fogalmaz: „Vajon az Enyedi-féle meghatározás szerinti sikeres városok kialakítását mely területekre fókuszálva, milyen módon segítheti a Modern városok program?"

A tanulmány első felében az MVP-t igyekszem tágabb kontextusba helyezni. Egyrészt történeti beágyazottságát, vagyis azt vizsgálom, hogy milyen, a városok (szükebben a megyei jogú városok) fejlesztését célzó programok tűntek fel, majd el az '50-es évektől kezdődően. Másrészt egy rövid kitekintésben arra keresem a választ, hogy a környező országokban koncepcionális szinten központilag koordinált-e a várospolitika. Noha a várospolitika és a városok megjelenése az uniós fejlesztéspolitikában, illetve az MVP elhelyezése az uniós kontextusban érdekes lenne, de a terjedelmi korlátok miatt erre nem vállalkozhattam.

A tanulmány második, nagyobb részében az MVP-t mint városfejlesztési programot elemzem. Érintőlegesen kapcsolódok más elemzési megközelítésekhez (városhálózat, várostérségek), hiszen a városfejlesztést nem lehet kiragadni a területi politika, illetve a területfejlesztés tágabb összefüggésrendszeréből. Ennek megfelelően a program koncepcióját, költségvetését, projektjeit, menedzsment-, illetve kommunikációs hátterét egyaránt vizsgálom.

\section{Az MVP helye a városfejlesztési koncepciók sorában}

A hazai városhálózat egységes fejlesztésével a 2. világháború utáni szocialista településhálózat-fejlesztési politika foglalkozott, amely szerint a településhálózat fejlődése 1949-ig tervszerűtlen és spontán volt. Az '50-es évek ideológiája szerint „a kapitalizmus időszakában a falu alávetett, kizsákmányolt helyzetbe került", ezért a szocializmus építésének előfeltétele, hogy a város és a falu közötti ellentétet megszüntessék (Hajdú 1989). A településhálózat fejlesztésének legfontosabb eszköze a szocialista iparosítás volt, amelyhez már a 609/31/1950. 
számú Népgazdasági Tanács határozata is osztályokba sorolta a településeket: az I. osztályban azon városok és községek találhatók, amelyeket átlagon felül kellett fejleszteni. E települések körének meghatározása a Területrendezési Intézet (TERINT) ${ }^{1}$ egyik első és legfontosabb kutatási feladata volt, amely alapján végül hetvenöt települést soroltak ide, amelyek népessége (Budapest nélkül) 1,9 millió főt tett ki (Hajdú 1989), ami majdnem megegyezik az MVP által érintett lakosok számával (1,98 millió fó). 1963-ban jelent meg az Országos településhálózat-fejlesztési tanulmányterv, amelyben a fejlesztések fókuszpontjai továbbra is a szocialista városok voltak (Rechnitzer 2018). Erre a tervre épülve készült el 1971-ben az Országos településhálózat-fejlesztési koncepció, amelynek az MVP szempontjából nézve fontos jellemzői, hogy a regionális központok fejlesztését tartotta fontosnak, valamint huszonhárom felsőfokú központot jelölt ki, amelyek szinte teljesen megfelelnek az MVP városainak (kikerült a huszonhárom város közül Baja, belekerült Érd).

A városhálózat és a területi közigazgatás problematikáját Bibó $(1975,143$. is tanulmányozta: „magától értetődő a közigazgatási területi beosztás és a városhálózat-fejlesztés párhuzamossága: nagyobb részben az előbbinek kell igazodnia az utóbbihoz". Bibó gondolata egybecseng az MVP azon koncepciójával, amennyiben a városok fejlesztését tekinti elsődlegesnek, és ehhez igazodik a területi rendszer, vagyis a városok a területi fejlesztések gócpontjai, vázai. A területi rendszer fontos eleme a középszint, a megye, amely Bibó $(1975,272$.$) sze-$ rint „könnyen ellentétbe kerül a városokkal is, amelyeket maga alá igyekszik rendelni." Ez kiváltképp érvényes megállapítás lehet a megyei jogú városokra, amelyek kapcsolata a megyékkel a mai napig ellentmondásos. Elég csak arra gondolni, hogy a tervek szerint az MVP-t is részben a Terület- és településfejlesztési operatív programból (továbbiakban TOP) finanszírozzák.

Az MVP - ahogy látni fogjuk - nem korlátozódik a városokra, hanem számos elemében érinti a városok környékét is, $\mathrm{s}$ ez véleményem szerint pozitívumnak tekinthető. A városkörnyékrendszerről Bibó azt írja: „Kedvez az erőteljes és nagyvonalú (községi szintet meghaladó) helyi önkormányzatnak és a város és vidék egybeszerveződésének" (Bibó 1975, 272.). Ez a gondolat is megjelenik az MVP-ben a térségi projekteknek köszönhetően, és a kormányzat ki is mondja, hogy az MVP egyik célja a városok térségszervező funkcióinak fejlesztése.

A hazai városhálózat fejlődése a rendszerváltozás után újra „tervszerűtlen és spontán" lett (Pirisi 2008; Szabó 2016; Szepesi 2008), két fontos jellemzője az önkormányzatok nagymértékü önállósága, valamint a városi rang tömeges megítélése volt. A városok fejlődésének, sikerességének három kulcsa a rendszerváltást követő két évtizedben a városvezetők (tágabban az intézményrendszer) hozzáállása, profizmusa, a térbeli elhelyezkedésből fakadó előnyök (jó elérhetőség) és a megfelelő fejlődési út kiválasztása volt - pl. az ipari átalakulás evolúciós pályáiról Lux (2017) ír részletesen könyvében. Az MVP nagyberuházásaival az első tényezőt jellemzően nem érinti (bár például Érden kiemelten fontos az intézményrendszer fejlesztése), a második tényezőt viszont 
fontosnak tartja (a cél az, hogy minden megyei jogú várost érjen el a gyorsforgalmi úthálózat). A fejődési út esetében vegyes a kép: van, ahol erősen támaszkodtak a meglévő hagyományokra (útfüggőség), máshol pedig új iparágak megtelepítésével próbálkoznak (útteremtés). Lux nyomán megválaszolandó kutatási kérdésnek tartom, hogy vajon az első esetben innovatív szerkezetváltásról, a második esetben pedig diverzifikációról van-e szó.

A hazai várospolitika az elmúlt három évtizedben sokat változott (Faragó 2006; Rechnitzer, Páthy, Berkes 2014), stabil, kiforrott koncepciója nem volt. A '90-es évek további jellemzője, hogy a fejlesztéspolitika előterébe a falusi térségek kerültek, kompenzálva a korábbi túlzott városcentrikusságot. Az 1996-os területfejlesztésről és területrendezésről szóló törvény nem definiálta a városok szerepét, az 1998-as Országos területfejlesztési koncepció (továbbiakban OTK) viszont már érdemben foglalkozott a városokkal, igaz, ez a hangsúly csak a tervekben jelent meg, a gyakorlatban kevésbé (Pálné Kovács 2008).

A városfejlesztés újabb szakasza az újjáalakuló és megerősödő területi tervezésnek köszönhetően indult el a kétezres évek közepén. Ennek fó oka az európai uniós jog-, intézmény- és tervezési rendszer adaptálása, tehát az Európai Unióhoz való csatlakozás volt. Az új területi tervezési intézményrendszer egyik első és legfontosabb dokumentuma a 2005-ös OTK. ${ }^{2}$ Ebben az egyik alapelv a város- és falufejlesztés, valamint az első átfogó cél a térségi versenyképesség, amelynek első pillére a centrumtérségek (fejlesztési pólusok) megerősítése. A középtávú célok közül is a második a „régiókat dinamizáló fejlesztési pólusok megerősítése és a városhálózati kapcsolatrendszer fejlesztése" (OTK 2005, 4.). Ezeket a fejlesztési pólusokat és alközpontokat nevesíti is az OTK, nem meglepő módon a megyei jogú városokat sorolja fel (Érd kivételével, amely az OTK elökészítése során még nem volt megyei jogú város). Az intézményrendszer tekintetében alapvetően más irányú volt az elképzelés (megye helyett régió, települési saját források bővítése stb.), mint napjainkban.

Az EU-csatlakozás nemcsak a tervezési rendszer és szemlélet átültetését hozta magával, hanem konkrét fejlesztéspolitikai dokumentumok elfogadását is. Ilyen volt a Lipcsei charta (2007), amely kimondta, hogy a városfejlesztést nemzeti szinten kell kezelni, de az országok kötelezettséget vállalnak a fenntarthatósági alapelvek és az integrált városfejlesztési eszközök meghonosítására, főként a kiegyensúlyozott területi fejlődés érdekében. Az MVP projektjei közül jó néhány támogatja a fenntarthatóság alapelvét (pl. elektromos buszok beszerzése és üzemeltetése), és a kiegyensúlyozott területi fejlődést is elősegítheti, hogy részben - ám sajnos csak szóban - egységes követelményeket támaszt egy „modern” várossal szemben a kormányzat. Az integrált városfejlesztési eszközöket a program egyáltalán nem alkalmazza: az integrált, többcsatornás, területegységekre és időre lebontott tervezési gyakorlat és az alulról építkező tervezés sem valósult meg, ami nagyban csökkenti a program hatékonyságát és hosszú távú fenntarthatóságát.

Az EU-csatlakozás a tervezés mellett a finanszírozásban is változást hozott: a városfejlesztés az európai uniós forrásoknak köszönhetően új lendületet ka- 
pott. Az első teljes uniós költségvetési ciklus (2007-2013) egyik legfontosabb eleme ebből a szempontból az integrált városfejlesztési stratégiák (IVS) kidolgozása - amelyet közel 100 település készített el 2007-ben Kukely (2015) szerint - és az abban megfogalmazott fejlesztések megvalósítása volt. Az IVS-ek kialakításának hazai tapasztalatairól Barta $(2009,1$.) ír: „az az általános hazai vélemény, hogy a városfejlesztés megújulása - különböző okok miatt - még várat magára.” Az egyik ok, hogy az „alapjaiban új szellemiségű városfejlesztési gondolkodást" nálunk fél év alatt kívánták bevezetni: 2007 októberében jelent meg a magyar kézikönyv, az IVS meglétét is feltételként támasztó városrehabilitációs pályázatokat pedig 2008 nyarán lehetett beadni úgy, hogy az egész IVS-t is ki kellett közben dolgozni. Ez a gyorsaság és a hirtelen bevezetés az MVP-re is jellemző. Az IVS egyik alapelve az alulról jövő kezdeményezések, elképzelések támogatása volt, ami azonban az MVP-ben csak nyomokban jelenik meg, hiszen a helyi vezetők állítottak össze egy kívánságlistát, és ezt vitatták meg a miniszterelnökkel.

A városok, illetve a városhálózat fejlesztését kifejezetten célzó programok, pályázati kírások tehát jellemzően az EU-csatlakozáshoz kapcsolódóan jelentek meg. Az egyik első ilyen kezdeményezés a 2004-2006-os ROP (Regionális operatív program) városi területek rehabilitációja című intézkedése volt, amelyben 2006-os árfolyamon közel 24 milliárd Ft-ot költöttek el a városi területek megújítására (Baráth, Szépvölgyi 2006). A 2007-2013-as időszakban a hét ROP keretében a térség- és kistérségfejlesztés, városrehabilitáció prioritás mentén 421 milliárd Ft beruházás valósult meg, amelynek célcsoportjai a városok voltak (ÁSZ 2015).

2014-ben, az új költségvetési ciklushoz kapcsolódóan integrált településfejlesztési stratégiát kellett készíteniük a megyei jogú városoknak is. Habár e dokumentumok közös alapokon nyugszanak, nemzeti szintű koordinációról nem beszélhetünk. Az MVP esetében elvileg igen, de a gyakorlatban nem jött létre a résztvevők közötti koordináció. A 2014-2020-as időszakban a városi fejlesztések fó forrása a Terület- és településfejlesztési operatív program (TOP), amelyben a 2. (Vállalkozásbarát, népességmegtartó településfejlesztés), a 6. (Fenntartható városfejlesztés a megyei jogú városokban) és a 7. (Közösségi szinten irányított városi helyi fejlesztések) prioritások érintik közvetlenül a városokat (nem csak a megyei jogúakat), összesen 561,4 milliárd Ft értékben (TOP 2018). Meg kell még említeni azt is, hogy a 1301/2013/EU rendelet 7. cikkelye meghatározza, hogy a nemzeti szintủ ERFA-források legalább 5\%-át a fenntartható városfejlesztésre kell fordítani. Látható, hogy egyre jelentősebb összegeket fordítottak a városok fejlesztésére, ebbe a trendbe az MVP is illeszkedik: a csak a megyei jogú városokat érintő projektek összköltsége 616,6 milliárd Ft.

A várospolitika nemzeti szinten részlegesen megjelenik az Országos fejlesztési és területfejlesztési koncepcióban (OFTK 2014), amely kiemeli, hogy a területi egyenlőtlenségek egyik oka „a funkcionális központ szerepét ellátó városok hiánya, és rossz elérhetőségük" (OFTK 2014, 84.), de arra is rámutat, hogy 
a térszerkezet átalakulásának nyertesei a nagyobb városok. Az MVP reflektál a városi funkciókra és az elérhetőségre, de mindezt a nagyobb városokat célozva teszi, tehát a korábbi, kedvezőbb pozícióban lévő nyerteseket erősíti tovább. Az OFTK területi specifikus céljai közül a második a többközpontú térszerkezetet biztosító városhálózat, amelynek első beavatkozási területe az egységes és fenntartható várospolitika megteremtése. Emellett az OFTK hangsúlyozza a funkcionális várostérségekben való gondolkodás fontosságát is. A 1567/2015. (IX. 4.) Korm. határozat elő is írja a nemzeti településpolitika (valamint annak cselekvési programja) elkészítését 2017. június 30-i határidővel, azonban ezek a dokumentumok egy évvel a határidő lejárta után sem érhetők el. Érdemes továbbá megemlíteni, hogy a kétezres évek első évtizedében készült egy Országos településhálózat-fejlesztési koncepció is, amelyet azonban nem fogadtak el.

Európában ugyan nem újdonság a városok előtérbe helyezése a területfejlesztésben, de az uniós fejlesztéspolitikában a városok javára bekövetkezett hangsúlyeltolódás csak a 2000-es évektől jellemző (Pálné Kovács 2008). A közeli országokra kitekintve vegyes kép fogad bennünket, ha egységes nemzeti várospolitikákat keresünk. A harmincöt OECD-ország közül csak tizenöt rendelkezik explicit nemzeti várospolitikával, de közülük is öt a tervezési fázisban van, tehát a szakpolitikai program készült még csak el (OECD 2017). Lengyelország 2015 végén fogadta el a Nemzeti várospolitika 2023 című dokumentumot, amely keretet ad és irányt mutat a városfejlesztésnek minden területi szinten, öt prioritást és tíz tematikus területet (pl. közösségi részvétel, közlekedés és mobilitás, beruházási politika) azonosít, amelyeknek meg kell jelenniük a helyi kezdeményezésekben, fejlesztési programokban. Csehországban 2010-ben fogadták el A várospolitika alapelvei című dokumentumot, amely útmutató a városfejlesztési tevékenységek koordinációjához a szektorok és a különböző területi kormányzási szintek között, és amely hat alapelvet fogalmaz meg (mint például az érintettek minél szorosabb bevonása vagy a várospolitika regionális szemlélete, azaz a város-vidék kapcsolatok fejlesztése). (OECD 2017)

Szlovákiában 2017-ben tervezés alatt állt egy városfejlesztési szakpolitika, amelynek elkészítésébe az érintettek széles körét vonták be. Szlovénia nem rendelkezik explicit várospolitikai dokumentummal, a téma Szlovénia területfejlesztési stratégiájában jelenik meg, abban viszont fontos elemként: a nyolc megfogalmazott prioritásból három kifejezetten a városokra vonatkozik. Végül Ausztria esetében sem beszélhetünk önálló várospolitikáról, itt is az Ausztriai területfejlesztési koncepció (ÖREK 2011) foglalja magába a városi területek fejlesztését, valamint az agglomerációs szakpolitikát. (OECD 2017)

A megyei jogú városok mint vidéki központok fejlesztésének tehát láthatóan van előzménye hazánkban. Érdekesnek tartom, hogy már 1950-ben is 1,9 milliós népességű várostömeget soroltak a kiemelten fejlesztendő csoportba, és ez a szám az MVP-ig is alig változott, csupán a városok száma csökkent. A településhálózat és azon belül a városhálózat egységes fejlesztése pedig máshol sem megoldott, amelynek okai között kereshetjük a probléma komplexitását (pl. hogy 
hány tématerülettel van szoros összefüggésben a városfejlesztés), a városok tipizálásának nehézségeit vagy a különböző politikai kurzusok változó szemléletét is.

\section{A Modern városok programja}

Az MVP a magyar várospolitika újabb fejezete, amely a magyar településhálózat speciális részét jelentő megyei jogú városokat érintik. Ezek a városok a legfontosabb vidéki központok - a legtöbbjük megyei központ is egyben -, és a megyéhez hasonló jogokkal bírnak. Az ötvenezer fö feletti népességü vidéki városaink mindegyike megyei jogú város, valamint a huszonegy legnagyobb vidéki város megyei jogú is egyben.

Magát a programot 2015. március 15-én, Sopronban indította útnak Orbán Viktor miniszterelnök (Merényi 2017), aki 2017. május 26-án látogatta meg az utolsó várost. A program lényege a kormányzati kommunikáció szerint az, hogy az elkövetkezendő négy-hét évre meghatározza a megyei jogú városok kiemelt fejlesztéseit, amelyeket a város és a kormány közötti együttműködési megállapodás szentesít. A programnak se kezdeti, se záró időpontja nem ismert. Az MVPben megfogalmazott projektek megvalósítását illetően az érintettek a 2019-2022-es évekről beszélnek. Egy projekt és egy program esetében is fontos tényező a pontos időbeli lehatárolás, ez azonban az MVP esetében eddig nem történt meg.

De milyen egy modern város a központi kormányzat szerint? „Nekünk, magyaroknak a modern város a magyar várost jelenti, amit a magyar temperamentum és észjárás alakít. Otthonos és családias közösséget, biztonságos környezetet, ahol van munkalehetőség, javulnak az életkörülmények, ahol minden megtalálható, elérhető helyben, ahol megbecsült embernek érezzük magunkat, ahol szépülnek az utcák, a terek, az épületek, ahol pezseg az élet" - fejtette ki a miniszterelnök (Orbán 2015). Ennél részletesebb magyarázatot nem kapunk, de a dokumentumokból több konkrétum is körvonalazódik arról, hogy milyen is (legyen) egy modern város:

- része a gyorsforgalmi úthálózatnak;

- minden térségszervező funkció tekintetében magas minőséget képvisel, e funkciói nem hiányosak (közlekedés, ipari-kereskedelmi infrastruktúra, közművek és közfunkciók, oktatás, egészségügy, rekreáció, turizmus);

- fejlett tömegközlekedéssel rendelkezik (pl. elektromos buszok, intermodális tömegközlekedési központ, ahol a vasútállomás és a buszvégállomás egy helyen van);

- megfelelő helyet tud biztosítani a beruházók számára;

- jellemzően rendelkezik egyedi, helyi tényezővel (pl. kulturális, természeti adottságok).

Az MVP tehát nem rendelkezik pontosan megfogalmazott koncepcióval, és konkrét elvárásokat, célokat egyik városra sem fogalmaz meg, így várospolitikai 
eszközként sérül az értelmezhetősége. A kiválasztott projektek javarészt az adott városok fejlesztési elképzeléseire épülnek, többnyire részei a városok folyamatosan alakuló fejlesztési koncepcióinak (pl. a debreceni Új főnix terv). A városok fejlesztési elképzeléseit 2014-től az integrált településfejlesztési stratégiák (ITS) tartalmazzák, az ITS-ek a helyzetelemzés és a középtávú célok megfogalmazása után akcióterületeket jelölnek ki, amelyekhez tételes fejlesztési projektlistát is csatolnak. Az ITS-ek projektjei szorosan épülnek a korábbi fejlesztési elképzelésekre, illetve főleg a 2007-es IVS-ekre. Az MVP projektjei is gyakran megjelennek a korábbi tervekben, ezt a Projektek alfejezetben részletezem.

Mivel az MVP nem rendelkezik elérhető központi adatbázissal a fejlesztésekről, mind a huszonhárom város esetében külön kutatást kellett folytatnom a minél pontosabb adatok megszerzéséhez. Ez az adatgyüjtési folyamat (amelyet 2018 szeptemberében zártam le) jelentette a kutatás leginkább időigényes részét, amelynek föbb forrásai az alábbiak voltak:

- a Miniszterelnökségen elérhető dokumentumok (együttműködési megállapodások és támogatási szerződések);

- helyi fejlesztési tervek, amelyekből MVP-s projektek lettek átemelve;

- települések hivatalos honlapja: hírek, részletesebb információk a projektek tervezéséről;

- helyi média: sajtótájékoztatók, hírek a fejlesztésekről;

- közgyülési anyagok: határozatok a beruházások előkészítéséről vagy megindításáról.

\section{Költségvetés}

A kutatás során kétszázötvennyolc projektet tudtam azonosítani, amelyekből huszonnyolc esetben becsült a költségvetés, kilenc esetben pedig még erre sem volt lehetőség, mivel a projekt tartalma sem tisztázható. Ráadásul a projektekhez rendelt összegek folyamatosan változnak, így pontos elemzésre csak fenntartásokkal alkalmasak a különböző, főleg helyi forrásokból összegyüjtött adatok. Nem tudható a fejlesztések forrásmegoszlása sem, azaz, hogy mekkora összeg áll rendelkezésre uniós, központi vagy helyi forrásból. A kutatás keretében 2 683,2 milliárd forintnyi projektet sikerült azonosítani, azonban a kormányzat 3 400-3 500 milliárd Ft-ot kommunikál a program összköltségeként (magyaridok.hu 2017) - a különbség jelentős.

Nehéz ezt a hatalmas összeget érdemben összehasonlítani más programokkal. A fejlesztések huszonhárom várost érintenek, amelyek népessége megközelíti a kétmillió főt, ami a vidéki lakosság közel negyedét jelenti. A Területfejlesztési operatív program (TOP) keretösszegéből 1 054,4 milliárd Ft-ot biztosít az EU, ehhez 173,2 milliárd Ft-ot tesz hozzá a központi költségvetés. A TOP 7 tengelye közül a legtöbb EU-s forrást a 6. tengely (Fenntartható városfej- 
lesztés a megyei jogú városokban) kapta 328 milliárd Ft-tal. A megyei jogú városok azonban - Csepreghy államtitkár szerint - az MVP összköltségének háromötödét (kb. 2100 milliárd Ft) uniós forrásból kapják majd (portfolio.hu 2017). Az ugyanakkor nem tisztázott, hogy pontosan milyen EU-s forrásból (a TOP-on felül). Amennyiben ez az elképzelés megvalósul, a megyei jogú városok egy főre jutó uniós támogatása kiemelkedő lesz, tehát kijelenthetjük, hogy a településfejlesztés nyertesei ebben a ciklusban ezek a városok lesznek. Arról nem készült nyilvános hatástanulmány, hogy mindez milyen hatással lesz a magyar településhálózatra, véleményem szerint mindenképpen a jelenleginél jóval kiegyensúlyozottabb fejlesztésekre lenne szükség.

A projekteket a hatékonyabb elemzés céljából funkcióik alapján kategorizáltam (1. ábra). A kategóriák közül talán csak az ipari és kereskedelmi infrastruktúrát érintő (leginkább iparterületek, de vásártér, áruforgalmi csomópont stb.), valamint a közösségi fejlesztéseket érdemes részletezni, utóbbi középületek, közösségi terek és közművek projektjeit tartalmazza.

1. ábra: Tervezett MVP-költségvetés ágazatonként (milliárd Ft)

Planned MCP budget by sectors (billion HUF)

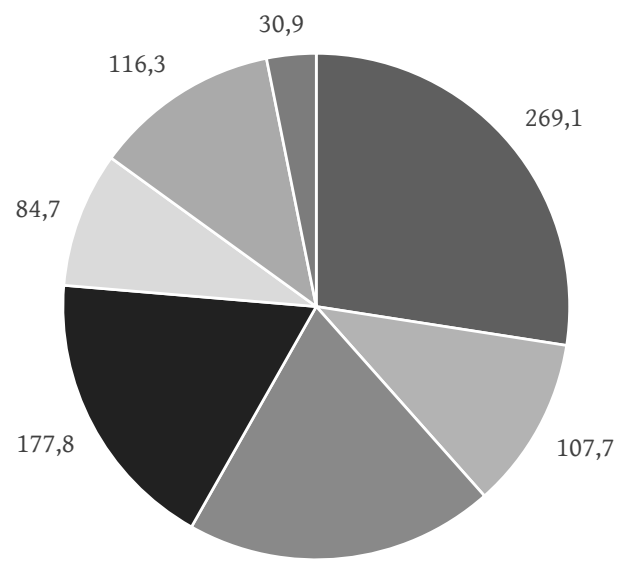

193,6

— Szűken vett közlekedés

Ipari és kereskedelmi infrastruktúra

nözösségi

- Sport

Turizmus

- Oktatás

- Egészségügy

Forrás: saját szerkesztés és adatgyüjtés.

A közlekedési projektek túlsúlya (78 db) mennyiségileg is jelentős $(30,2 \%)$, de a költségvetésben még nagyobb a súlyuk (73,5\%). Ennek a fó oka a gyorsforgalmi utak és vasútfejlesztések megjelenése a programban. A közlekedésfejlesztés 1 972,2 milliárd forintjából 1 703,1 milliárd tartozik a gyorsforgalmi utak és a 
1. táblázat: Modern városok program: a beruházások településenkénti megoszlása Modern Cities Program: Distribution of the investments by settlements

\begin{tabular}{lcccc}
\hline \multicolumn{1}{c}{ Város } & $\begin{array}{c}\text { Népesség (ezer fö, } \\
\text { 2015) }\end{array}$ & $\begin{array}{c}\text { MVP-projektek ter- } \\
\text { vezett költségvetése } \\
\text { (milliárd Ft) }\end{array}$ & $\begin{array}{c}\text { Szüken vett MVP- } \\
\text { költségvetés* } \\
\text { (milliárd Ft) }\end{array}$ & $\begin{array}{c}\text { Egy före jutó MVP- } \\
\text { költségvetés* } \\
\text { (ezer Ft/fó) }\end{array}$ \\
\hline Békéscsaba & 60334 & 399,6 & 72,6 & 1203,3 \\
Debrecen & 203506 & 46,3 & 46,3 & 227,5 \\
Dunaújváros & 46052 & 37,6 & 37,6 & 816,5 \\
Eger & 54609 & 41,6 & 20,8 & 380,9 \\
Érd & 63993 & 41,0 & 41,0 & 640,7 \\
Győrr & 129372 & 91,5 & 66,5 & 514,0 \\
Hódmezővásárhely & 44795 & 42,8 & 20,8 & 464,3 \\
Kaposvár & 63742 & 152,4 & 47,6 & 746,8 \\
Kecskemét & 111836 & 160,4 & 57,3 & 512,4 \\
Miskolc & 159554 & 189,9 & 39,9 & 250,1 \\
Nagykanizsa & 48241 & 55,6 & 34,3 & 711,0 \\
Nyíregyháza & 118125 & 54,9 & 36,9 & 312,4 \\
Pécs & 145985 & 264,2 & 35,5 & 243,2 \\
Sajgótarján & 35811 & 107,1 & 57,1 & 1594,5 \\
Sopron & 61780 & 118,9 & 8,9 & 144,1 \\
Szeged & 162593 & 106,6 & 56,2 & 345,6 \\
Szekszárd & 33032 & 36,4 & 36,4 & 1102,0 \\
Székesfehérvár & 98673 & 73,2 & 73,2 & 741,8 \\
Szolnok & 72786 & 131,2 & 11,2 & 153,9 \\
Szombathely & 77866 & 131,8 & 31,8 & 408,4 \\
Tatabánya & 66791 & 56,0 & 56,0 & 838,4 \\
Veszprém & 60761 & 57,8 & 57,8 & 951,3 \\
Zalaegerszeg & 58959 & 286,4 & 34,4 & 583,5 \\
\hline Összesen & 1979196 & 2683,2 & 980,1 & 495,2 \\
\hline
\end{tabular}

* Gyorsforgalmi utak és vasútfejlesztések nélkül.

Forrás: saját szerkesztés és adatgyüjtés.

vasutak fejlesztéséhez. Ezeket a beruházásokat kihagyva is 269,1 milliárd Ft-tal a közlekedésre jut a legtöbb pénz, de a kép kiegyensúlyozottabb. Mindenképpen érdekes az egészségügyre jutó források alacsony szintje ( $1,2 \%$, a nagy közlekedésfejlesztési beruházások nélkül 3,2\%). Ennek hátterében a korábbi jelentős kórházfejlesztési beruházások állnak, amelyek jellemzően a megyei jogú városokat érintették.

A teljes költségvetés városonkénti megoszlását a nagy különbségek miatt nem érdemes értelmezni. A szüken vett költségvetés alapján Békéscsaba és Győr kapta a legnagyobb egy före jutó összeget, míg Sopron a legkevesebbet. A legnagyobb összeg 8,2-szerese a legkisebb összegnek (1. táblázat).

A tervezett költségek további jellemzője az összegek jelentős változása. Ennek egyik oka a funkciók bővülése vagy a projektkoncepció pontosítása lehet, 
2. táblázat: MVP-projektek tervezett költségvetésének jelentősebb változásai (milliárd Ft) Significant changes in the budget of MCP projects

\begin{tabular}{lcc}
\hline \multicolumn{1}{c}{ Projekt } & $2015-16$ & 2018 \\
\hline Debreceni innovációs fejlesztések & 5,0 & 23,0 \\
Kaposvári közlekedési központ & 12,0 & 10,5 \\
A 67-es út négysávúsítása & 77,0 & 104,8 \\
Kaposvári sportcsarnok & 4,0 & 5,7 \\
Kaposvári uszoda & 4,0 & 5,7 \\
A kaposvári kórházépület hasznosítása & 2,0 & 4,5 \\
Kecskeméti koncertterem, tantermek és stúdió építése & 3,0 & 4,5 \\
A kecskeméti városháza felújítása & 3,0 & 5,2 \\
Zalaegerszegi gyorsforgalmi út & 90,0 & 150,0 \\
\hline
\end{tabular}

Forrás: saját szerkesztés és adatgyüjtés.

de több esetben erről nincs szó, mégis jelentős a tervezett költségek növekedése. A 2. táblázatban azon projekteket tüntettem fel, amelyek tervezett költségvetése legalább 30\%-kal vagy 1,5 milliárd Ft-tal módosult bármelyik irányban. A második oszlopban az egyes projektek tervezett költségét tüntettem fel az első bejelentéskor vagy más fejlesztési tervekben (pl. megyei ITP, ITS), a harmadik oszlopban pedig a 2018-ban elérhető adatokat.

\section{Projektek}

Érdemes megvizsgálni a projektek ágazati megoszlását (2. ábra). Tipikus projektek a - több városban intermodális - közlekedési központ fejlesztése, iparterület kialakítása, színházak felújítása, különböző sportcentrumok és hotelek építése, valamint a középfokú (jellemzően fizikai szakmákhoz kapcsolódó) oktatási intézmények felújítása, bővítése.

Békéscsaba az élelmiszeriparra és a nyomdaiparra koncentrál, Debrecen jelentős összeget ( 5 milliárd Ft) kíván innovációra költeni (részletek nem ismertek), Dunaújvárosban pedig a logisztikai központ a legnagyobb beruházás, amelyet már évtizedek óta tervez a város. Eger a történelmi várra fókuszál, míg Érd hiányzó térségi központi funkcióit kívánja pótolni (pl. rendőrkapitányság, ügyészség, bíróság). Győr kulturális kapacitását kívánja továbbfejleszteni, kapcsolódva az Európa Kulturális Fővárosa pályázatához is. Hódmezővásárhely - a tramtrain mellett - kerékpárútra és naperőmüre ruházna be nagyobb tételben. Kaposvár számára a fö prioritás a sport és az egészségügy, míg Kecskeméten egy 25 milliárd Ft-os fejlesztési alap jelenik meg projektként, valamint a vasútfejlesztés a legjelentősebb tétel.

Miskolc projektjei erősen differenciáltak, míg Nagykanizsa a sportra és a turizmusra koncentrál. Nyíregyházának van jelentősebb projektje a közösségi 


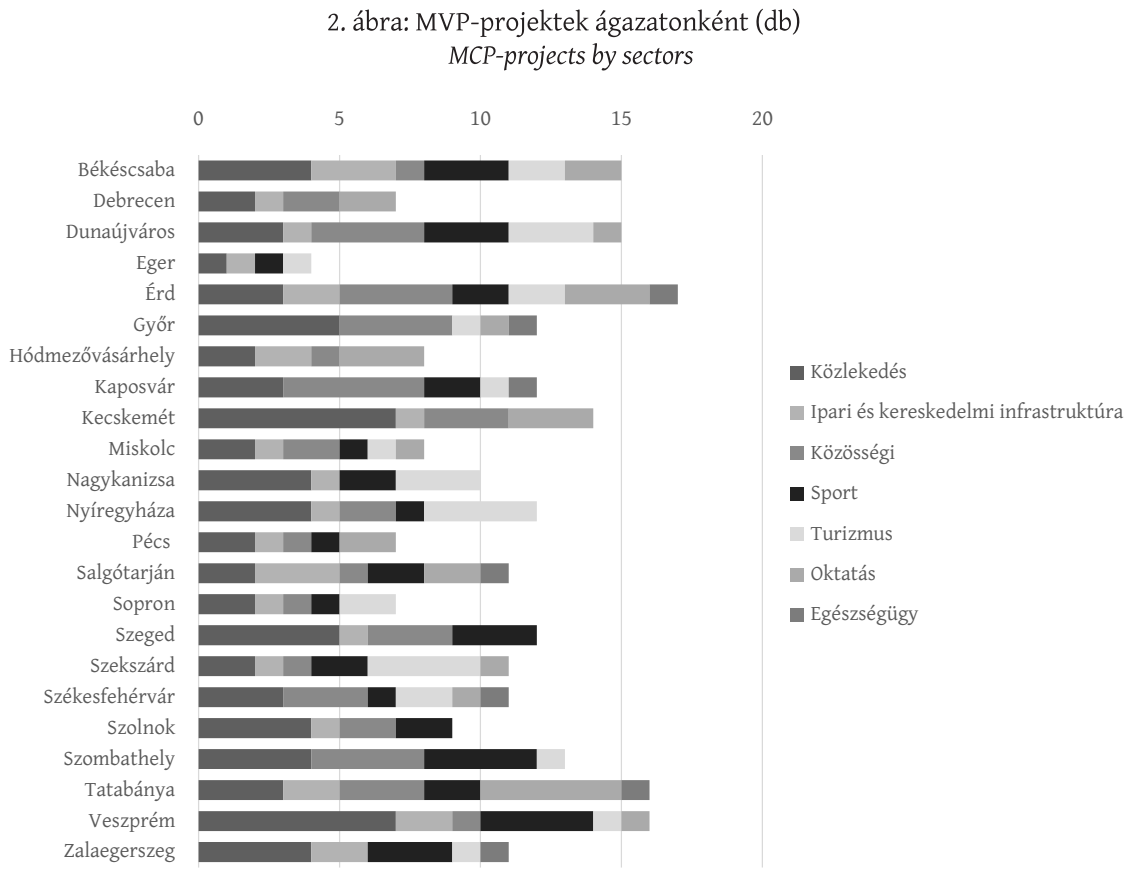

Forrás: saját szerkesztés és adatgyüjtés.

közlekedés, az ipari infrastruktúra, a sport és a turizmus terén is. Pécs költségvetésének túlnyomó részét (80\%-át, 28,5 milliárd Ft-ot) az egyetem fejlesztésére fordít - a beruházások a tervek szerint az egyetem minden karát érintik majd (pte.hu 2017). Salgótarján esetében a legnagyobb tétel (22 milliárd Ft) egy részleteiben nem ismert regionális fejlesztési terv. Sopron fő prioritása a turizmus (pl. hotel építése). Szeged leginkább a közösségi közlekedését és a sportintézményeit kívánja fejleszteni, míg Szekszárdon a legnagyobb beruházás az új távfütési rendszer kiépítése lesz, amely egyedi projekt az MVP-ben.

Székesfehérvár programja kiegyensúlyozott az ágazatokat tekintve, jelentős projekteket terveznek megvalósítani a közlekedés, a turizmus, az oktatás és a kultúra terén is. Szolnok esetében a strand- és fürdőfejlesztést érdemes kiemelni. Szombathelyen a sport és a turizmus a legerősebb irány, míg Tatabánya és Veszprém szintén kiegyensúlyozott projektlistát állított össze, számszerüleg is sok projekttel. Végül Zalaegerszeg a sportra, valamint az egészségügyre és a turizmusra koncentrál.

Az ipari parkok kialakítása terén - amely tizennyolc várost érint az MVP-ben, így megéri a külön figyelmet - a hazai gazdaságfejlesztésben új elemként megjelent a Nemzeti Ipari Park Üzemeltető és Fejlesztő Zrt. (továbbiakban NIPÜF) cégcsoport. Az állami tulajdonú szervezet Inpark márkanév alatt alakít ki elsősorban a megyei jogú városokban ipari parkokat. A cég 2015 
decemberében alakult, a Kormány pedig 2016 júniusában döntött az országos iparipark-koncepció megvalósításáról. Az iparipark-hálózat megvalósításához kapcsolódó beruházások összértéke 150-200 milliárd Ft, amely Európa legnagyobb ilyen jellegü ingatlanfejlesztési programja (inpark.hu 2017). A kormányhatározat szerint (1268/2016. VI.7.) nemcsak az MVP ipari parkjainak fejlesztése, tervezése és kivitelezése lesz a NIPÜF feladata, de az intermodális csomópontok tervezésében, kivitelezésében és üzemeltetésében is részt kell vennie. Az erős centralizáció újabb jelét láthatjuk tehát, amely azonban ebben az esetben indokolt, hiszen az ipari parkok jellemzően nem a helyi közösség speciális igényeit, hanem a beruházó vállalkozások általánosabb igényeit elégítik ki. Emellett Magyarország egységesen fellépve jelentősebb tényező lehet a nemzetközi iparterületi piacon, mint egy-egy város globális szemmel nézve jelentéktelen méretű ipari parkja. Ráadásul területi felzárkóztatás csak úgy re-

3. táblázat: MVP-projektek megjelenése korábbi tervekben Appearance of the MCP projects in former plans of the cities

\begin{tabular}{|c|c|c|c|c|c|}
\hline Város & $\begin{array}{c}\text { MVP projektek } \\
(d b)\end{array}$ & $\begin{array}{c}\text { Megjelenés me- } \\
\text { gyei ITP-ben } \\
(d b)\end{array}$ & $\begin{array}{c}\text { Megjelenés helyi } \\
\text { tervekben }(d b)\end{array}$ & $\begin{array}{l}\text { Megjelenés me- } \\
\text { gyei és helyi ter- } \\
\text { vekben }(\mathrm{db})\end{array}$ & $\begin{array}{c}\text { Illeszkedési } \\
\text { arány (\%) }\end{array}$ \\
\hline Békéscsaba & 15 & 4 & 4 & 6 & 40 \\
\hline Debrecen & 7 & 4 & 3 & 4 & 57 \\
\hline Dunaújváros & 15 & 10 & 8 & 12 & 80 \\
\hline Eger & 4 & 3 & 2 & 3 & 75 \\
\hline Érd & 17 & 8 & 11 & 14 & 82 \\
\hline Győr & 12 & 0 & 7 & 7 & 58 \\
\hline Hódmezővásárhely & 8 & 0 & 5 & 5 & 63 \\
\hline Kaposvár & 12 & 9 & 1 & 9 & 75 \\
\hline Kecskemét & 14 & 7 & 11 & 11 & 79 \\
\hline Miskolc & 8 & 4 & 4 & 5 & 63 \\
\hline Nagykanizsa & 10 & 2 & 2 & 3 & 30 \\
\hline Nyíregyháza & 12 & 4 & 0 & 4 & 33 \\
\hline Pécs & 7 & 1 & 1 & 1 & 14 \\
\hline Sajgótarján & 11 & 2 & 0 & 2 & 18 \\
\hline Sopron & 7 & 0 & 3 & 3 & 43 \\
\hline Szeged & 12 & 6 & 1 & 7 & 58 \\
\hline Szekszárd & 11 & 3 & 1 & 3 & 27 \\
\hline Székesfehérvár & 11 & 7 & 2 & 7 & 64 \\
\hline Szolnok & 9 & 0 & 0 & 0 & 0 \\
\hline Szombathely & 13 & 0 & 0 & 0 & 0 \\
\hline Tatabánya & 16 & 3 & 1 & 4 & 25 \\
\hline Veszprém & 16 & 3 & 6 & 6 & 38 \\
\hline Zalaegerszeg & 11 & 0 & 4 & 4 & 36 \\
\hline Összesen & 258 & 80 & 77 & 120 & 47 \\
\hline
\end{tabular}

Forrás: saját szerkesztés. 
mélhető, ha a jelentősebb beruházások az elmaradottabb térségekben (illetve azok központjaiban) valósulnak meg.

A projektlistákat a helyi politikai vezetés állította össze, részben a korábbi fejlesztési elképzelésekre támaszkodva. A korábbi tervekhez való kapcsolódás megismerése érdekében megvizsgáltam a 2016 (azaz az MVP) előtti megyei ITP-ket, valamint a városi ITP-ket és ITS-eket. Látható, hogy az MVP-projektek közel fele már korábbi fejlesztési tervekben is megjelent. Vitakérdés lehet, hogy vajon ez sok vagy kevés, a szórás mindazonáltal igen nagy: Szolnok és Szombathely is teljesen új projektötleteket hozott az MVP-be (0\%-os illeszkedés), míg Dunaújváros erősen épített a meglévő elképzelésekre (80\%) (3. táblázat).

Végül a projekteket abból a szempontból is vizsgálhatjuk, hogy mennyire térségi szemléletűek, hatásúak. E tekintetben három kategóriát határoztam meg: térségi (több települést érint), funkciójában térségi (a fejlesztés a városban valósul meg, de a térség veszi igénybe, pl. kórház, színház, felsőoktatási intézmény), illetve városi (jellemzően csak a városlakók használják). Negyvenkét projekt (16\%) térségi, hatvanegy (24\%) csak funkciójában az, míg százötvenöt (60\%) városi hatókörü. A nagy közlekedési infrastrukturális projekteket (harminc db) kihagyva - amelyek nyilván mind térségi hatásúak - azonban mások az arányok: térségi 5\%, funkciójában térségi $27 \%$, városi $68 \%$. Ezen arányok értékelése újfent vitatéma lehet: véleményem szerint kimutathatóan megjelenik a várostérség, illetve a térségi központ gondolata, bár a térségi projektek nagyobb aránya vélhetően kedvezőbb hatással lenne egy egészséges város-vidék kapcsolatra.

\section{Menedzsment és kommunikáció}

A MVP megvalósításának mikéntjéről a 250/2016. (VIII. 24.) kormányrendeletből tájékozódhatunk. A támogatások odaítéléséről a háromfős MVP-bizottság dönt. Támogatás a központi költségvetés Miniszterelnökség fejezetében megállapított, Modern városok program elnevezésű előirányzat terhére nyújtható, de ettől a kormány eltérhet. A bizottság munkájáról nem érhető el jegyzőkönyv, így nem ismert az ülések száma, dátuma, tartalma, illetve a résztvevők köre.

A 2017-es központi költségvetésben a Modern városok programja soron 825 millió Ft található a program múködtetésére a Miniszterelnökség fejezetében, és 152 milliárd Ft a tényleges beruházásokra (2016. évi XC. tv.). 2016-ban a tervezett összeg 50 milliárd Ft volt, míg 2015-ben 25 milliárd Ft, amiből mindössze 1 milliárd Ft valósult meg, de az is a Helyi önkormányzatok támogatásai fejezetben (4. táblázat). A 2018-as költségvetésben 23,3 milliárd Ft jelenik meg az MVP-soron működési céllal, és 133,7 milliárd Ft felhalmozás céllal.

Mivel a részletekről nincs információ, csak annyi állapítható meg, hogy a MVP első két éve főleg a tervezéssel és újratervezéssel telt, igazi lendületet a program 2017-től kapott. Ennek érdekében a kormány új, megyei jogú városok 
4. táblázat: MVP források megoszlása (milliárd Ft)

Distribution of the MCP sources (billion HUF)

\begin{tabular}{|c|c|c|c|}
\hline$E ́ v$ & Hazai & EU-s & Összesen \\
\hline 2015 & 1 & n. a. & 1 \\
\hline 2016 & 50 & 140 & 190 \\
\hline 2017 & 152 & 100 & 252 \\
\hline Összesen & 203 & 240 & 443 \\
\hline
\end{tabular}

Forrás: saját szerkesztés.

fejlesztéséért felelős tárca nélküli miniszteri posztot hozott létre 2017 októberében, amely azonban 2018 áprilisa után betöltetlen maradt. 2017-ben májusig 172,4 milliárd Ft hazai forrás és 64 milliárd Ft uniós forrás kifizetése történt meg (Híradó 2017). A tervek szerint 2018-ban az 1000 milliárd Ft-ot is elérhette az MVP költségvetése (magyaridok.hu 2017) - ehhez szükség is volt az irányítás megerősítésére, hiszen az első három évben (a négy-hétévesre tervezett ido"szakból) a becsült költségvetés csupán 17\%-a kerül elköltésre.

A megvalósulás felgyorsítását segíti a kiemelt beruházási státusz, amelyet több nagyberuházás is megkap annak érdekében, hogy a bürokratikus előkészítő folyamatok egyszerűsödjenek és felgyorsuljanak. A gyorsítás azonban magával hozza a helyi közösségek ellenőrző funkciójának gyengülését, s növeli annak az esélyét, hogy a megvalósuló beruházás nem pontosan a helyi közösség igényeinek felel meg.

Az MVP-vel kapcsolatban ki kell térnünk a helyi menedzsmentre is, amely változatos formát mutat a különböző városokban, és ahogy a központi irányítás, úgy ez is folyamatosan változik. Győrben, ahol a városi kormányzás más területen is erős és hatékony (Fekete 2017a), az MVP-vel kapcsolatos teendőket polgármesteri biztos felügyeli három munkatársa segítségével. Ez azonban elszigetelt eset, a polgármesteri hivatalok jellemzően nem alakítottak ki külön alrendszert az MVP-projektek menedzseléséhez.

A nagy nemzeti kezdeményezések - már csak jelentőségüknél fogva is - fontos szerepet tölthetnének be a központi kormányzat kommunikációjában, azonban a programmal kapcsolatos központi kommunikáció is esetleges: nincs tájékoztató alhonlap vagy akár rendszeres sajtótájékoztató az előrehaladásról, és a helyi szereplők kommunikációja is igen eltérő (5. táblázat). Meglepő, hogy Győr, amely a menedzsment terén jó példát mutat, valamint a városmarketing és kommunikáció más területein is magas szintű tevékenységet folytat, az MVP-kommunikáció esetében milyen gyengén teljesít.

A városok esetlegesen tartanak sajtótájékoztatókat a témában, amelyek a projektek előrehaladásáról - pl. alapkő lerakása, átadás - tájékoztatják a lakosságot. A városok hivatalos közösségi oldalain, ahogy a helyi újságok honlapjain nincs külön tartalom az MVP-hez kapcsolódóan. Összességében megállapítható, hogy a kommunikáció szintje messze elmarad attól, mint amit a program jelentősége és az abban rejlő kommunikációs lehetőségek indokolnának. 
5. táblázat: MVP-vel kapcsolatos tartalom a városok honlapján (2018. szeptember) MCP contents on the websites of the cities (September 2018)

\begin{tabular}{ll}
\hline \multicolumn{1}{c}{ Város } & \multicolumn{1}{c}{ Tartalom } \\
\hline Békéscsaba, Érd & Menüpont a főoldalon \\
\hline $\begin{array}{l}\text { Debrecen, Dunaújváros, Eger, Kecskemét, Nyír- } \\
\text { egyháza, Salgótarján, Szeged, Szombathely, Vesz- } \\
\text { prém, Zalaegerszeg }\end{array}$ & Kapcsolódó hírek a honlap keresőjében \\
\hline Győr & $\begin{array}{l}1 \mathrm{db} \text { hír a honlap keresőjében, valamint a polgár- } \\
\text { mesteri biztos feltüntetése a szervezetben }\end{array}$ \\
\hline $\begin{array}{l}\text { Hódmezővásárhely, Miskolc, Nagykanizsa, Pécs, } \\
\text { Sopron, Szekszárd, Tatabánya }\end{array}$ & Nincs érdemi információ \\
\hline Kaposvár & Külön menüpont (Németh István program) rövid \\
& projektleírásokkal \\
\hline Székesfehérvár & $\begin{array}{l}\text { Részletes adatok a projektekröl, de nehéz megta- } \\
\text { lálni, csak kereséssel sikerült }\end{array}$ \\
\hline Szolnok & $\begin{array}{l}\text { A föoldalon üres rész MVP címmel, és egy Mo- } \\
\text { dern város menüpont a beruházások híreivel }\end{array}$ \\
\hline
\end{tabular}

Forrás: saját szerkesztés.

\section{Konklúziók és javaslatok}

Fekete veti fel kérdésként (2017b, 102.), hogy „vajon jelent-e új városfejlesztési rezsimet a Modern városok programja." Mindenképpen új irányról beszélhetünk: egy erősen centralizált, az érintettek bevonását háttérbe szorító, szinte „kézi vezérlésű” rendszerről. Fejlesztési rezsimnek viszont véleményem szerint nem tekinthetö, hiszen azok ismertetője, hogy „közös célokat tűznek ki, és megosztják a hatalmat (döntéshozást) és a feladatokat is. Ehhez természetesen szükséges a szereplők megfelelő autonómiája is" (Gajzágó 2018, 138.). A bevonás és a társadalmasítás hiánya miatt közös célokról túlzás beszélni. A döntések megosztásával éppen ellentétes, amit az MVP képvisel. A szereplők autonómiája a központi kormányzaton kívül csupán névleges.

Kérdésként merül fel, hogy az MVP fejlesztései új fejlődési utat jelentenek-e az egyes városok számára. Mivel a városok projektjeinek koherenciája meglehetősen gyenge, nem határozható meg karakterisztikus fejlődési irány egyik város esetében sem. Általánosságban a már kitaposott, sikeres úton haladnak tovább a fejlesztések (pl. győri kulturális és egyetemi fejlesztések), vagy a meglévő potenciál kiaknázására építenek (pl. békéscsabai Munkácsy-negyed, érdi Papi földek, zalaegerszegi Mindszenty-zarándokhely). Utóbbiak jellemzően turisztikai irányultságúak. Összességében új fejlődési irányokról nem beszélhetünk, csupán a korábbi fejlődési utak kisebb korrekciójáról, például a turizmus vagy az oktatás erősítéséről.

Az MVP projektjeivel több ponton is érinti Enyedi (1997) városi sikertényezőit, meglátásom szerint a következők szerint. Egyrészt az MVP lehetőséget 
ad a gazdasági szerkezet módosítására, másrészt szinte minden város esetében megjelennek az értékhúzó szolgáltató szektori fejlesztések (pl. oktatás, kutatásfejlesztés). A tudásalapú termelés és az innováció megjelenése viszont nem általános, mindössze kilenc városban azonosítható ilyen projekt. Az MVP célja a megyei jogú városok mint térségi központok erősítése is, azonban nem mondhatjuk, hogy a fontos (akár vállalati, akár kormányzati) döntések helyben születnének. Az erős és gyarapodó középosztály nem jellemző a magyar társadalomban (Veres 2017), de ha valahol javult a helyzetük, akkor valószínűleg leginkább a térségi központokban.

A nagy értékü környezet mint városi sikertényező tekintetében mindenképpen erős az MVP, hiszen minden városban megjelenik a közösségi helyek (parkok, színházak stb.) megújítása. A konfliktuskezelés fejlesztése viszont egyáltalán nem része és célja a programnak. A külső kapcsolatokat Enyedi szerint is erősítik a nagy közlekedési fejlesztések, emellett a logisztikai központok, az intermodális közlekedési csomópontok, de a szállodai fejlesztések is, e tekintetben az MVP projektjei sikeresek lehetnek. Végül a növekvő jövedelem és a foglalkoztatás bővítése mindenképpen célja és hatása az MVP-nek: itt föleg az ipari fejlesztések hordozhatnak pozitív hatásokat. Összességében tehát az MVP és projektjei részben megfelelnek a városi sikeresség Enyedi által azonosított klasszikus tényezőinek - az egyelőre nyitott kérdés marad, hogy mi és hogyan valósul majd meg a tervekből.

Kissé távolabbról tekintve pozitív fejlemény, hogy van a nagyobb térségi központok fejlesztésére egy bizonyos elemeiben egységes elképzelés, bár ez nem leírt, bárki számára hozzáférhető koncepció. A program nem teljesen tisztázott céljai is elfogadhatók, támogatandók. Emellett néhány jelentős kockázat is felmerül a program megvalósításával kapcsolatban:

- több projekt nincs megtöltve tartalommal, sok projekt ötletszerü;

- a legtöbb projekt költségvetése nem kellően alátámasztott;

- a tervezés és megvalósítás folyamataiból hiányzik az átláthatóság;

- a program teljes költségvetése eléri a magyar GDP 9\%-át, tehát hatalmas összegről van szó, ehhez képest mind a koordináció, mind a kommunikáció fejlesztésre szorul;

- a városhálózat fejlesztése kiegyensúlyozatlan: a kisebb városok, járási központok a háttérbe szorulnak.

A kormányzat számára szakpolitikai javaslatként az alábbiakat fogalmazhatjuk meg:

- javítani szükséges a program átláthatóságát egy központi honlap létrehozásával, ahol elérhetőek az MVP-bizottság jegyzőkönyvei és dokumentumai, a projektek listája és állása, valamint a városok kapcsolódó oldalai;

- a helyi közösségek bevonását erősíteni kell, ehhez központilag is egységes ajánlásokat kell megfogalmazni, és információt, valamint a reagálásra szükséges időt is biztosítani kell;

- a program adta kommunikációs lehetőségeket érdemes jobban kihasználni: ezt főleg helyi szinten kell erősíteni az online média bevonásával 
(hivatalos honlap, közösségi média, helyi online újságok stb.);

- a menedzsmentfolyamatokat is fejleszteni szükséges, e területen is érdemes központi ajánlásokat megfogalmazni a városok felé;

- az egyes projektek tartalmát és főleg költségvetését ésszerüsíteni szükséges, így javítva a hatékonyságot és a megvalósíthatóság esélyét.

A fejlesztések társadalmi elfogadottsága jónak mondható: egyrészt egy fejlesztésnek - érintsen bármilyen területet - jellemzően örülnek egy közösség tagjai, másrészt az MVP-projektek nagy része nem alap és előzmény nélküli, hanem valamilyen helyi igényre reflektál.

Azt azonban látnunk kell, hogy a városhálózat meghatározó elemeiben jelentős változás csak évtizedes és rendkívül sok energiát és erőforrást igénylő munkával érhető el. Ahogy a korábbi várospolitikai kezdeményezések a legjobb esetben is csupán részeredményeket értek el megfogalmazott céljaikhoz képest, úgy az MVP esetében is várható, hogy menet közben elfogy a lendület, illetve a politikai motiváció. Ezt vetítik előre a tanulmányban megfogalmazott kritikai megjegyzések is.

Összességében bár az MVP egy újabb eszköze a várospolitikai fejlesztéseknek, Magyarország továbbra sem rendelkezik egységes várospolitikával, és a településhálózat fejlesztése továbbra sem megalapozott vagy kiegyensúlyozott. Azonban az MVP megvalósulása pozitívan hathat a térségi központokra, fóként akkor, ha a kormányzat nyitott a közösségek és szakemberek érdeklődésére és javaslataira.

\section{Jegyzetek}

1 A TERINT az Újjáépítési és Közmunkaügyi Minisztérium elemző intézete volt a 2. világháború után, amely 1949-ben alakult önálló intézetté.

2 Megjegyzendő, hogy már az 1998-as OTK-ban szerepel az innovációs és vállalkozói centrum funkcióját betöltő vidéki központok megerősítésének célja, felsorolás nélkül.

\section{Köszönetnyilvánítás}

A tanulmány elkészítését az NKFIH 115577. számú szerződése (A hazai középvállalati szektor szerepe az ipar területi versenyképességében) támogatta.

\section{Irodalom}

ÁSZ (2015): Tanulmány a 2007-2013. évi EU költségvetési időszakban Magyarország részére juttatott közösségi támogatások összefoglaló bemutatásáról, értékeléséról. Állami Számvevőszék, Budapest 
Barta Gy. (2009): Integrált városfejlesztési stratégia: A városfejlesztés megújítása. Tér és Társadalom, 3. 1-12. http://doi.org/c85h

Bibó I. (1975): Közigazgatási területrendezés és az 1971. évi településhálózat-fejlesztési koncepció. Budapest. http://mek.oszk.hu/02000/02043/html/433.html (Letöltés: 2017. március 10.)

Enyedi Gy. (1997): A sikeres város. Tér és Társadalom, 4., 1-7. http://doi.org/c85j

Faragó L. (2006): A városokra alapozott területpolitika koncepcionális megalapozása. Tér és Társadalom, 2., 83-102. http://doi.org/czm7

Fekete D. (2017a): Európai járműipari térségek gazdasági kormányzási modelljei. Tér és Társadalom, 3., 125-142. http://doi.org/czm8

Fekete D. (2017b): A Modern Városok Program elemzési lehetőségei. Polgári Szemle, 1-3., 94-105. http://doi.org/czk9

Gajzágó G. (2018): A fejlesztési rezsim gyakorlata Dunaújvárosban. In: Fata I., Gajzágó É., Schuchmann J. (szerk.): Regionális folyamatok a változó világban és Magyarországon: Tanulmánykötet Enyedi György professzor emlékére. Tomori Pál Főiskola, Budapest, 137-147.

Hajdú Z. (1989): Az első szocialista településhálózat-fejlesztési koncepció formálódása Magyarországon. Tér és Társadalom, 1., 86-96. http://doi.org/c85k

Kukely Gy. (2015): Gazdaságfejlesztés az integrált településfejlesztési stratégiákban. In: Városi válaszok a globális gazdasági kihivásokra és technológiai trendekre különös tekintettel az intelligens városok modelljére. Magyar Urbanisztikai Társaság, Budapest, 65-83.

Lux G. (2017): Újraiparosodás Közép-Európában. Dialóg Campus Kiadó, Pécs

Merényi M. (2017): Eleredt a pénzeső: Térképre visszük a Modern városok program kifizetéseit. http://k.blog.hu/2017/02/09/eleredt_a_penzeso_potyognak_a_milliardos_beruhazasok_a_ modern_varosokra (Letöltés: 2017. február 26.)

OECD (2017): National urban policy in OECD countries. OECD Publishing, Paris

Orbán V. (2015): Vonzóvá kell tenni Székesfehérvár városát. http://www.kormany.hu/hu/ a-miniszterelnok/beszedek-publikaciok-interjuk/vonzova-kell-tenni-szekesfehervarvarosat (Letöltés: 2016. november 24.)

Pálné Kovács I. (2008): Az új várospolitika kormányzási filozófiája, Tér és Társadalom, 1., 45-57. http://doi.org/c2bn

Pirisi G. (2008): A magyar kisvárosok differenciált fejlődése a rendszerváltozás után. Pécsi Tudományegyetem, Pécs

Rechnitzer J. (2018): Nagyvárosok a magyar területi politikában és területfejlesztésben a rendszerváltozástól napjainkig. Tér és Társadalom, 1., 3-26. http://doi.org/c85m

Rechnitzer J., Páthy Á., Berkes J. (2014): A magyar városhálózat stabilitása és változása. Tér és Társadalom, 2., 105-127. http://doi.org/c2bp

Szabó J. (szerk.) (2016): URB.0 Urbanisztika kezdőknek. BME Urbanisztika Tanszék, Budapest http://www.urbanisztika.bme.hu/urb-0-urbanisztika-kezdoknek/ (Letöltés: 2018. augusztus 22.)

Szepesi G. (2008): A rendszerváltozás utáni várossá avatások Magyarországon. Tér és Társadalom, 2., 53-70. http://doi.org/c85n

TOP (2018): TOP 2017 Polgároknak szóló összefoglaló. Miniszterelnökség, Budapest, https://www. palyazat.gov.hu/download.php?objectId=78145 (Letöltés: 2018. október 11.)

Veres M. (2017): Kik a vesztesek? Jövedelemarányok változása Magyarországon 2010 óta. GKI Gazdaságkutató Zrt., Budapest https://www.gki.hu/language/hu/2017/07/04/kik-a-vesztesek-jovedelem aranyok-valtozasa-magyarorszagon-2010-ota/ (Letöltés: 2017. szeptember 14.)

http://inpark.hu/projektek/ (Letöltés: 2017. március 10.)

https://www.kormany.hu/hu/dok?source=7\&type=414\#! DocumentBrowse (MVP együttműködési megállapodások és támogatási szerződések)

http://magyaridok.hu/belfold/csepreghy-nandor-modern-varosok-program-mas-mint-az-eddigiek1913545/ (Letöltés: 2017. január 26.)

http://www.portfolio.hu/unios_forrasok/gazdasagfejlesztes/csepreghy_az_osszes_eu-penzrol_ dontest_hozunk_jovo_tavaszig.1.243062.html (Letöltés: 2017. január 28.)

https://pte.hu/modern_varosok_program (Letöltés: 2017. február 24.) 